\title{
Analisa posisi derajat tonjolan magnet (trigger magnet) pada konsumsi bahan bakar
}

\author{
Fatkur Rhohman ${ }^{1)}$, Susdi Subandriyo ${ }^{2)}$, Hesti Istiqlaliyah ${ }^{3)}$ \\ ${ }^{1,2,3)}$ Program Studi Teknik Mesin, Univ. Nusantara PGRI Kediri \\ E-mail: ${ }^{1}$ fr_kediri@yahoo.com, ${ }^{2}$ susdi1995@gmail.com, ${ }^{3)}$ Hestiisti@unpkediri.ac.id
}

\begin{abstract}
Abstrak
Dalam dunia otomotif, banyak dilakukan berbagai modifikasi untuk meningkatkan performa mesin. Salah satu yang dilakukan adalah dengan memaksimalkan pembakaran yang terjadi di ruang bakar. Dengan memaksimalkan sistem pengapian dalam proses pembakaran, diharapkan dapat memperbesar percikan bunga api dari busi. Salah satu komponenyang mempengaruhi proses pembakaran adalah Magnet, berfungsi untuk menimbulkan listrik yang akan menjadi arus listrik tegangan tinggi dan memungkinkan terjadinya loncatan bunga api pada busi. Dalam penelitian ini, variabel bebasnya adalah modifikasi tregger magnet yang dimundurkan 0,50 , menjadi $9,5^{\circ}$ dan $9^{0}$, secara umum tidak terdapat perbedaan signifikan. nilai $F_{\text {hitung }}$ untuk hasil pada jenis trigger magnet $=3.00$ $\mathbf{F}_{(0.05 ; 2 ; 24)}=3,40$ (ditolak $\mathbf{H}_{0}$ ) artinya memundurkan tonjolan magnet (trigger magnet) $9^{0}$ dan 9,5 $5^{0}$ tidak berpengaruh secara signifikan. Selain itu, $F_{\text {hitung }}$ untuk hasil putaran mesin rpm 6000, 7000, 8000 menghasilkan $=1.00<\mathrm{F}_{(0.05 ; 2 ; 24)}=3,40\left(\right.$ ditolak $\left.\mathrm{H}_{0}\right)$ artinya tingkat putaran mesin tersebut tidak berpengaruh secara signifikan. Jadi tidak ada pengaruh konsumsi bahan bakar pada trigger magnet yang dimodifikasi, maupun pada rpm 6000, rpm 7000 dan rpm 8000.
\end{abstract}

Kata Kunci: trigger magnet, konsumsi bahan bakar, modifikasi

Abstract

In automotive, many various modifications are made to improve engine performance. One that is done is to maximize the combustion that occurs in the combustion chamber. By maximizing the ignition system in the combustion process, it is expected to enlarge sparks from spark plugs. One of the components affecting the combustion process is Magnet, serves to generate electricity that will become a high voltage electric current and allow the occurrence of spark jumps on the spark plug. In this study, the independent variable is the modified tregger magnet which is reversed 0.50, to 9.50 and 90. in general there is no significant difference. Fcount value for result on magnetic trigger type $=3.00<F(0.05 ; 2.24)=3.40$ (rejected HO) means reversing the 90 and 9.50 magnetic triggers does not significantly influence. In addition, Fcount for 6000, 7000, 8000 rpm engine yield $=1.00<F(0.05 ; 2.24)=3.40$ (Rejected H0) means the engine's rotation rate has no significant effect. So there is no effect of fuel consumption on the modified magnetic trigger, nor at rpm 6000, rpm 7000 and rpm 8000.

Keywords: trigger magnet, fuel consumption, modification 


\section{PENDAHULUAN}

Dalam dunia otomotif, banyak dilakukan berbagai modifikasi untuk meningkatkan performa mesin. Salah satu yang dilakukan adalah dengan memaksimalkan pembakaran yang terjadi di ruang bakar. Dengan memaksimalkan sistem pengapian dalam proses pembakaran, diharapkan dapat memperbesar percikan bunga api dari busi, yang akan digunakan untuk melakukan proses pembakaran antara campuran udara dan bahan bakar di ruang bakar [1]. Jika campuran bahan bakar dan udara bisa terbakar dengan sempurna, akan menyebabkan kinerja motor menjadi meningkat.

Pembakaran yang terjadi dalam sebuah motor bakar akan menentukan besarnya tenaga yang dihasilkan oleh motor tersebut[2]. Tenaga yang dihasilkan oleh motor merupakan hasil dari pembakaran yang terjadi di dalam silinder. Pembakaran pada motor bensin terjadi dengan diawali dari terhisapnya campuran bahan bakar dan udara ke dalam silinder yang kemudian dinyalakan dengan percikan bunga api dari busi, dimana proses ini terjadi pada saat akhir langkah kompresi. Persamaan kimia dari pembakaran yang sempurna adalah sebagai berikut:

$\mathrm{C} 8 \mathrm{H} 18+12 \frac{1}{2} \mathrm{O} 2+47 \mathrm{~N} 2 \rightarrow 8 \mathrm{CO} 2+9 \mathrm{H} 2 \mathrm{O}+47 \mathrm{~N} 2$

Pembakaran yang terjadi akan diiringi dengan peningkatan suhu pembakaran yang berkisar antara $2100^{\circ} \mathrm{K}$ sampai $2500^{\circ} \mathrm{K}$ dalam ruang bakar[3].

Sistem pengapian merupakan sistem yang digunakan untuk menghasilkan bunga api, guna melakukan pembakaran terhadap campuran bahan bakar udara yang ada di dalam ruang pembakaran dengan waktu pengapian (timing ignition) yang telah ditentukan. Untuk tercapainya loncatan bunga api pada busi, maka harus ada tengangan listrik yang cukup tinggi yang berkisar antara 5.000 volt sampai lebih tinggi dari 10.000 volt[4].

Adapun komponen-komponen sistem pengapian, antara lain:

a. Magnet. digunakan untuk menimbulkan listrik yang akan menjadi arus listrik tegangan tinggi dan memungkinkan terjadinya loncatan bunga api pada busi

b. busi (busi iridium dan busi platinum) berfungsi untuk menciptakan loncatan bunga api saat dialiri arus listrik tegangan tinggi

c. CDI (capacitive discharge ignition), berfungsi sebagai pengatur pengapian (ignition) dan kelistrikan (electricity) yang terdapat pada sebuah sepeda motor dan berperan membaca sensor yang mengatur waktu pengapian yang terdapat pada mesin lalu diolah secara digital dalam CDI. Hasil pemrosesan CDI berupa output yang akan mengatur perangkat pengapian untuk melakukan pembakaran (combustion) bahan bakar di dalam ruang bakar (combustion chamber) sebuah mesin sepeda motor.

d. Koil, mengubah sumber tegangan rendah dari baterai atau koil sumber (12 volt) menjadi sumber tegangan tinggi (10 volt atau lebih) yang diperlukan untuk menghasilkan loncatan bunga api yang kuat pada celah busi dalam pengapian, kabel busi tegangan tinggi,

e. Pulser, membaca tonjolan (trigger magnet) terdapat pada sisi luar pelat dudukan (sitting) magnet. Magnet yang terhubung dengan crank shaft akan berputar sesuai dengan putaran mesin, semakin tinggi putaran mesin akan semakin tinggi pula putaran magnet yang akan berpengaruh terhadap pembacaan pulser terhadap tonjolan sisi luar sitting plate magnet

Setelah terjadinya proses campuran bahan bakar oleh bunga api, maka diperlukan waktu tertentu bagi bunga api untuk merambat di dalam ruang bakar. 
Oleh sebab itu akan terjadi sedikit kelambatan antara awal pembakaran dengan pencapaian tekanan pembakaran maksimum. Dengan demikian, agar diperoleh output maksimum pada engine dengan tekanan pembakaran mencapai titik tertinggi (sekitar 100 setelah TMA (titik mati atas)), periode perlambatan api harus diperhitungkan pada saat menentukan saat pengapian (ignition timing) untuk memperoleh output mesin yang semaksimal mungkin. Akan tetapi karena diperlukan waktu untuk perambatan api, maka campuran udara bahan bakar harus dibakar sebelum TMA.

Loncatan bunga api terjadi sesaat torak mencapai TMA sewaktu langkah kompresi. Saat loncatan bunga api biasanya dinyatakan dalam derajat sudut engkol sebelum torak mencapai TMA. Pada pembakaran sempurna setelah penyalaan dimulai, api menjalar dari busi dan menyebar ke seluruh arah dalam waktu yang sebanding dengan 200 sudut engkol atau lebih untuk membakar campuran sampai mencapai tekanan maksimum. Kecepatan api umumnya kurang dari 10-30 m/detik. Panas pembakaran dari TMA diubah dalam bentuk kerja dengan efisiensi yang tinggi. Kelambatan waktu akan menurunkan efisiensi. Hal ini disebabkan rendahnya tekanan akibat pertambahan volume dan waktu penyebaran api yang terlalu lambat. Bila proses pembakaran dimulai dari awal sebelum TMA (menjahui TMA) tekanan hasil pembakaran meningkat, sehingga gaya dorong piston meningkat (kerja piston menuju gas pada ruang bakar). Jika proses sudut penyalaan dimundurkan mendekati TMA, maka tekanan hasil pembakaran maksimum lebih rendah bila dibandingkan tekanan hasil pembakaran maksimum, bila sudut penyalaan dimulai normal. Hal ini dikarenakan, pada saat sudut penyalaan terlalu dekat dengan TMA. Pada saat busi memercikan bunga api dan api mulai merambat, gerakan piston sudah melewati TMA sehingga volume ruang bakar mulai membesar. Sehingga walaupun terjadi kenaikan tekanan hasil pembakaran, sebagian telah diubah menjadi perubahan volume ruang bakar. Efek yang terjadi adalah kecilnya kerja ekpansi yang diterima oleh piston[5].

Dari uraian di atas, peneliti tertarik untuk memodifikasi piranti yang bertugas memperkuat percikan bunga api pada busi, sehingga daya yang dihasilkan menjadi optimal. Modifikasi yang dilakukan adalah dengan merubah derajat tonjolan magnet (trigger magnet) pada sepeda motor standar. Setelah dilakukan modifikasi, selanjutnya adalah menentukan pengaruh perubahan derajat tenjolan magnet (trigger magnet) terhadap konsumsi bahan bakar.

Specific Fuel Consumption (SFC) merupakan perbandingan antara bahan bakar yang terpakai sebagai input energi dengan daya yang dihasilkan sebagai output. Semakin tinggi nilai Specific Fuel Consumption, maka semakin banyak energi bahan bakar yang tidak terkonversi menjadi daya. Hal ini disebabkan karena bahan bakar yang masuk ke dalam silinder tidak terbakar dengan sempurna. Konsumsi bahan bakar spesifik ini, merupakan parameter prestasi mesin yang digunakan untuk mengukur nilai ekonomis suatu mesin, karena dengan mengetahui konsumsi bahan bakar spesifik maka dapat dihitung jumlah bahan bakar yang dibutuhkan per jam untuk menghasilkan sejumlah daya.

\section{METODE PENELITIAN}

Alur penelitian yang dilakukan dalam penelitian ini dapat digambarkan dalam diagram alir berikut ini. 


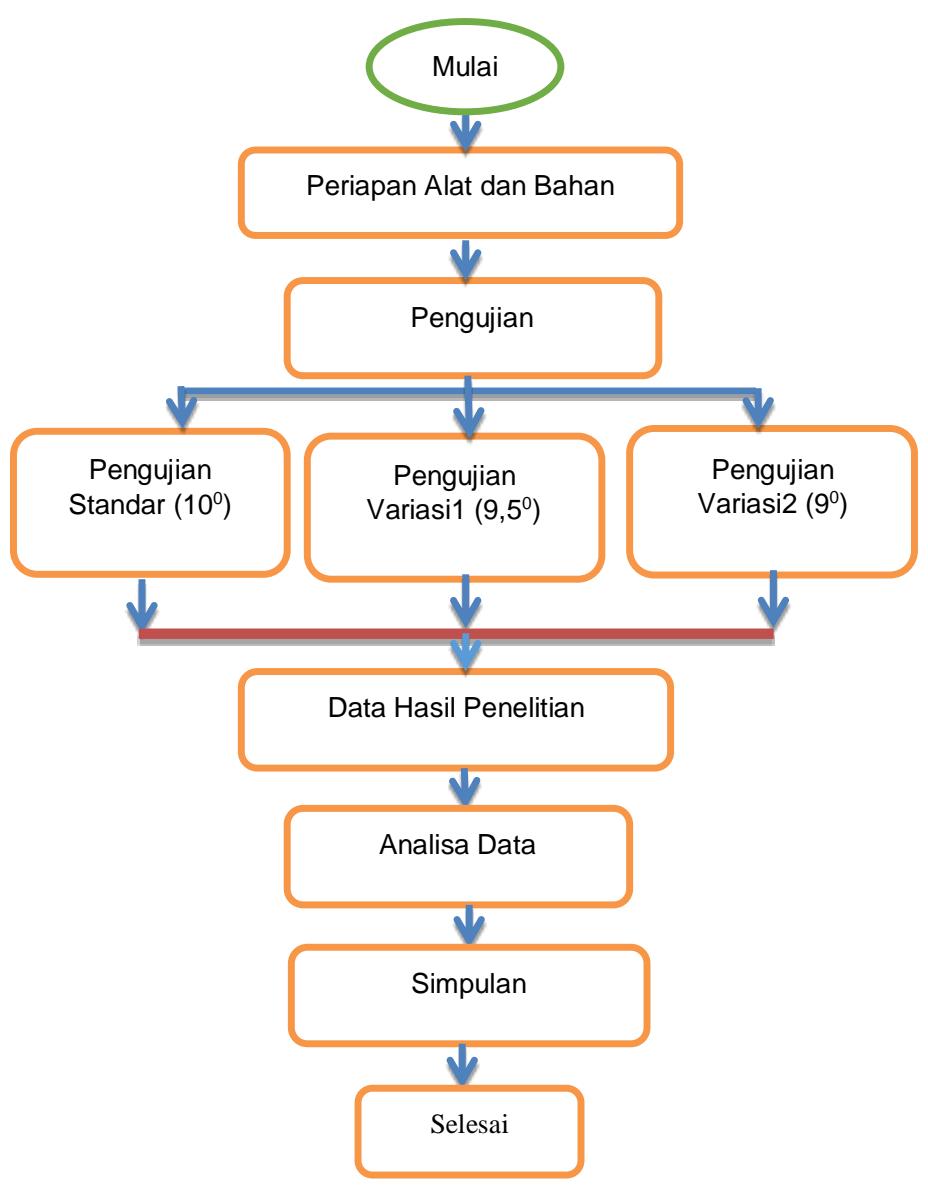

Gambar 1. Diagram alur penelitian

Variable penelitian yang digunakan sebagai berikut:

a. Variabel bebas : posisi derajat tonjolan magnet $10^{\circ}, 9,5^{\circ}$ dan $9^{0}$.

Dasar pemilihan derajat modifikasi tersebut adalah karena dari penelitian Machmud, yang memajukan $3^{0}$ dari posisi normal, dan $6^{0}$ dari posisi normal. Hasilnya komsumsi bahan bakar yang paling rendah didapatkan pada tregger magnet yang dimajukan $6^{0[6]}$. Sehingga peneliti mengambil perlakuan dengan modifikasi mundur $0,5^{0}$.

b. Variabel Terikat : Konsumsi bahan bakar

c. Variable kontrol : Sepeda motor 125 CC, Putaran mesin 6000-8000 rpm kelipatan 1000, Jenis bahan bakar pertamax.

Adapun dalam penelitian ini, urutan proses kerja pengambilan data adalah sebagai berikut:

a. Memasang magnet standar pada obyek penelitian

b. Mesin dihidupkan pada putaran idle selama \pm 5 menit agar mesin bisa mencapai suhu kerja yang optimal.

c. Setelah kondisi mesin ideal, dilakukan menggunakan alat ukur Dynotest.

d. Pengukuran diambil pada saat kecepatan motor 6000, 7000, dan $8000 \mathrm{rpm}$.

e. Melakukan pengukuran konsumsi bahan bakar yang dihasilkan pada putaran mesin $6000 \mathrm{rpm}$ sampai $8000 \mathrm{rpm}$ dengan kelipatan 1000 dengan waktu 1 menit. 
f. Mesin dimatikan dan di istirahatkan sejenak, setelah itu mengganti triger magnet

\section{HASIL DAN PEMBAHASAN}

Dari hasil penelitian pengujian konsumsi bahan bakar (SFC), diperoleh data sebagai berikut:

Table 1. Hasil pengujian Konsumsi Bahan Bakar (SFC) trigger magnet

\begin{tabular}{|ccccc|}
\hline Rpm & $\begin{array}{c}\text { Konsumsi } \\
\text { Bahan Bakar } \\
\text { (SFC) dengan } \\
\text { tregger magnet } \\
10^{\circ}\end{array}$ & $\begin{array}{c}\text { Konsumsi } \\
\text { Bahan Bakar } \\
\text { (SFC) dengan } \\
\text { tregger magnet } \\
9,5^{\circ}\end{array}$ & $\begin{array}{c}\text { Konsumsi } \\
\text { Bahan Bakar } \\
\text { (SFC) dengan } \\
\text { tregger magnet }\end{array}$ & \\
\hline $\mathbf{6 0 0 0}$ & $16 \mathrm{ml}$ & $24 \mathrm{ml}$ & $28 \mathrm{ml}$ & $22,67 \mathrm{ml}$ \\
\hline $\mathbf{7 0 0 0}$ & $20 \mathrm{ml}$ & $28 \mathrm{ml}$ & $32 \mathrm{ml}$ & $26,67 \mathrm{ml}$ \\
\hline $\mathbf{8 0 0 0}$ & $28 \mathrm{ml}$ & $24 \mathrm{ml}$ & $28 \mathrm{ml}$ & $26,67 \mathrm{ml}$ \\
\hline & $21,33 \mathrm{ml}$ & $25,33 \mathrm{ml}$ & $29,33 \mathrm{ml}$ & \\
\hline
\end{tabular}

Dari data di atas, diketahui konsumsi bahan bakar rendah diperoleh pada saat Rpm 6000 , yaitu sebesar 22,67 ml. Sedangkan pada modifikasi tregger magnet, konsumsi bahan bakar yang paling irit adalah pada tregger magnet 10o, yaitu $21,33 \mathrm{ml}$. Namun perlu dilakukan pengujian lanjutan dari data tersebut, apakah perubahan data tersebut berpengaruh signifikan apa tidak.

Selanjutnya, dilakukan uji normalitas. Uji normalitas ini dilakukan untuk mengetahui apakah data variabel yang ada di penelitian ini berdistribusi normal atau tidak. Dalam analisis data ini peneliti menggunakan taraf signifikan kesalahaan sebesar $\alpha=5 \%(0,05)$, dengan kata lain tingkat keyakinannya adalah 95\%. Dalam uji normalitas ini peneliti menggunakan software Minitab 16, yang menghaslikan plot normalitas sebagai berikut :

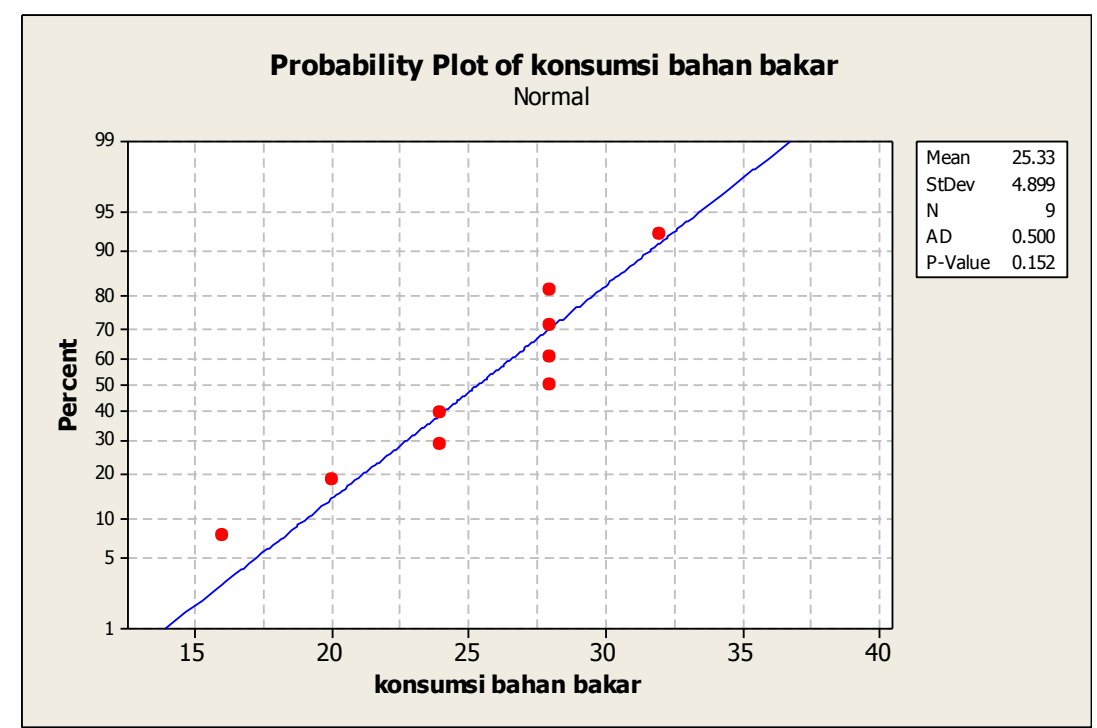

Gambar 2. Plot uji normalitas pada konsumsi bahan bakar mesin

Analisa posisi derajat tonjolan magnet (trigger magnet) pada konsumsi bahan bakar (Fatkur Rhohman) 
Dari data P-Value, diketahui nilainya adalah 0,152. Nilai P-Value tersebut lebih besar dari $\alpha=5 \%(0.05)$. Sehingga dapat disimpulkan bahwa data tersebut berdistribusi normal.

Setelah uji normalitas dilakukan, selanjutnya dilakukan uji identik. Uji identik ini dilakukan untuk mengetahui apakah ada penelitian yang didapat identik atau tidak. Bila sebaran data pada output uji ini tersebar secara acak dan tidak membentuk pola tertentu disekitar harga nol maka data memenuhi asumsi identik. Namun bila output uji ini tersebar secara tidak acak dan membentuk pola tertentu disekitar harga nol maka data tidak memenuhi asumsi identik yang diperlukan. Berikut plot uji identik konsumsi bahan bakar menggunakan Minitab 16.

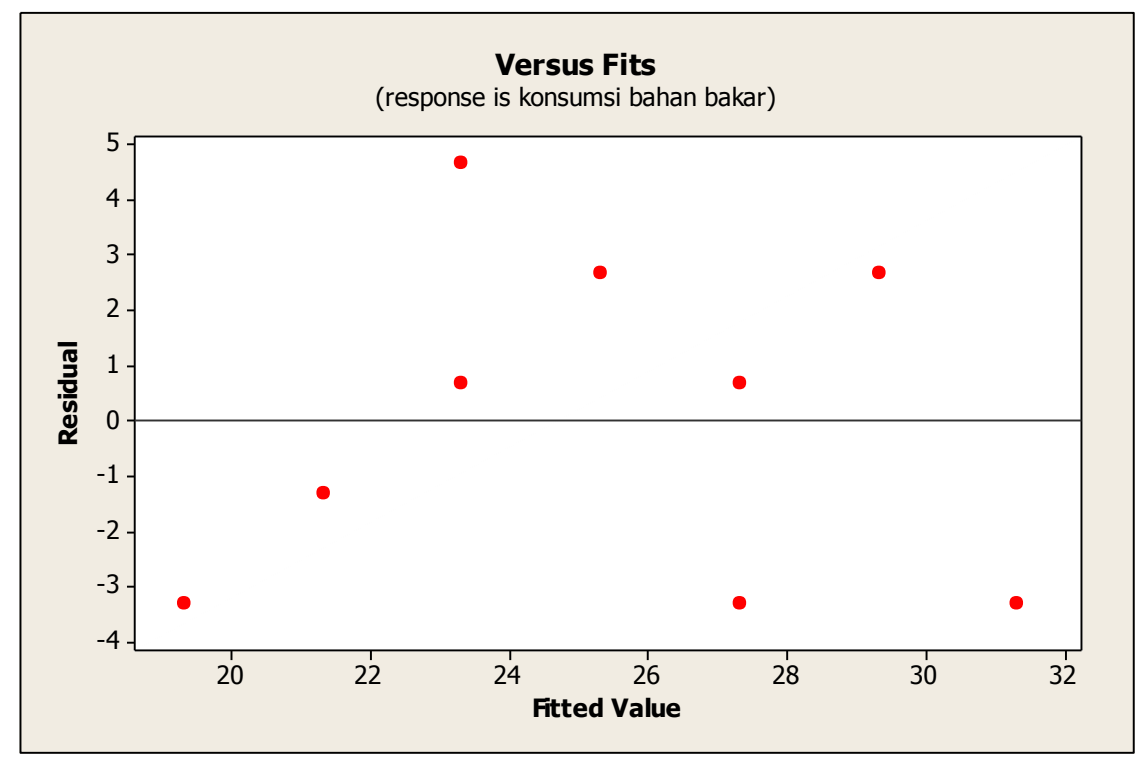

Gambar 3. Residual plot konsumsi bahan bakar pada uji identik.

Dari gambar tersebut, diketahui bahwa sebaran data tidak membentuk pola tertentu, atau tersebar secara acak. Sehingga disimpulkan bahwa data memenuhi asumsi identik.

Uji independen ini digunakan untuk mengetahui apakah data hasil pengukuran dalam eksperimen telah lepas dari pengaruh hasil pengukuran lainnya atau tidak. Dalam uji independen ini peneliti masih menggunakan software Minitab 16 dengan auto correlation function (ACF) untuk mengetahui apakah terdapat nilai ACF yang keluar dari batas interval atau tidak. Bila tidak terdapat nilai yang melebihi interval maka data penelitian ini memenuhi asumsi indentik, namun bila terdapat data penelitian yang melebihi batas interval maka terdapat hasil pengukuran yang terpengaruh oleh hasil pengukuran lainnya. Berikut plot hasil uji independen data ini dari output Minitab 16. 


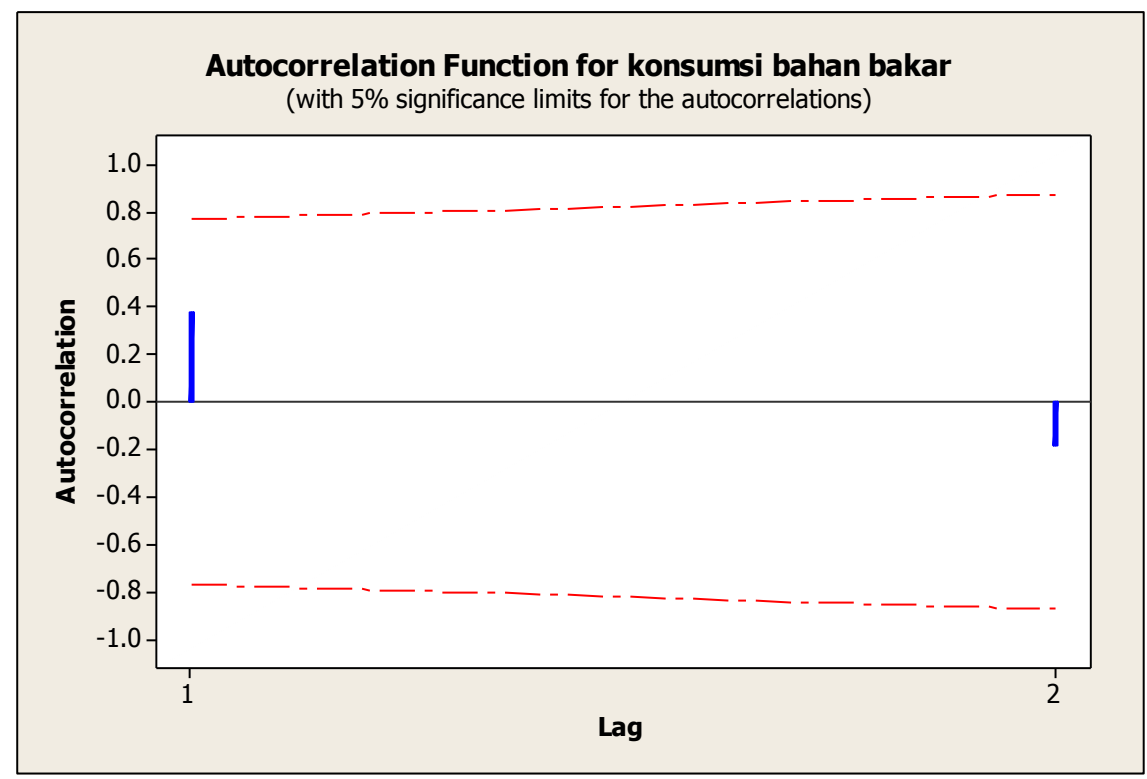

Gambar 4. Plot ACF konsumsi bahan bakar pada variabel respon trigger magnet

Pada gambar 4.9 menunjukan tidak terdapat nilai ACF yang keluar dari interval uji independen. Hal ini menandakan bahwa variabel respon penelitian ini bersifat independen. Dalam analisis varian (Anova) ini peneliti menggunakan software Minitab 16 untuk menguji apakah ada pengaruh yang diberikan variabel bebas secara simultan terhadap Daya, Torsi, dan Konsumsi Bahan Bakar (sfc) pada mesin. P-Value dapat digunakan untuk menguji hipotesis awal. Hipotesis awal (HO) akan ditolak bila P-Value kurang dari nilai taraf signifikan $\alpha$ (dalam penelitian ini nilai $\alpha$ yang digunakan adalah $5 \%$ atau $\alpha=(0,05)$. Berikut hasil analisa varian yang peneliti uji melalui software Minitab 16.

Tabel 2. General Linear Model: konsumsi bahan b versus jenis trigger magnet, rpm

$\begin{array}{llrl}\text { Factor } & \text { Type } & \text { Levels Values } \\ \text { jenis trigger magnet } & \text { fixed } & 3 & 9.0,9.5,10.0 \\ \text { fixed } & 3 & 3000,7000,8000\end{array}$

Analysis of Variance for konsumsi bahan bakar, using Adjusted SS for Tests

$\begin{array}{lrrrrrr}\text { Source } & \text { DF } & \text { Seq SS } & \text { Adj SS } & \text { Adj MS } & \text { F } & \text { P } \\ \text { jenis trigger magnet } & 2 & 96.00 & 96.00 & 48.00 & 3.00 & 0.160 \\ \text { rpm } & 2 & 32.00 & 32.00 & 16.00 & 1.00 & 0.444 \\ \begin{array}{l}\text { Error } \\ \text { Total }\end{array} & 4 & 64.00 & 64.00 & 16.00 & & \\ & 8 & 192.00 & & & & \\ \text { S }=4 \quad \mathrm{R}-\mathrm{Sq}=66.67 \% & \mathrm{R}-\mathrm{Sq}(\mathrm{adj})=33.33 \%\end{array}$

Dari tabel 2, dapat kita ketahui bahwa pada pengujian konsumsi bahan bakar mesin variabel jenis trigger magnet mendapat P-Value sebesar 0.160. Sedangkan untuk variabel rpm mendapat P-Value sebesar 0.444 . 
Tabel 3. Persentase kontribusi konsumsi bahan bakar untuk setiap faktor penelitian

\begin{tabular}{cccc}
\hline Variabel bebas & Df & Seq SS & \% kontribusi \\
\hline Jenis trigger magnet & 2 & 96.00 & 50 \\
Rpm & 2 & 32.00 & 16.66 \\
\hline Error & 4 & 64.00 & 33.33 \\
Total & 8 & 192.00 & 100 \\
\hline
\end{tabular}

Dari tabel 3, dapat kita ketahui bahwa variabel trigger magnet mempunyai kontribusi sebesar 50\% sedangkan variabel rpm mendapat nilai sebesar $16.66 \%$ dan terdapat nilai error sebesar $33.33 \%$.

Pada pengujian analisa Ftabel varians terhadap konsumsi bahan bakar yang memiliki nilai Fhitung untuk hasil pada jenis trigger magnet $=3.00<\mathrm{F}(0.05 ; 2,24)$ $=3,40$ (ditolak $\mathrm{H}_{0}$ ) artinya memundurkan tonjolan magnet (trigger magnet) 90 dan 9,50 tidak berpengaruh secara signifikan. Sedangkan Fhitung untuk hasil putaran mesin rpm 6000, 7000, 8000 menghasilkan $=1.00<\mathrm{F}(0.05 ; 2,24)=3,40$ (ditolak $\mathrm{H} 0$ ) artinya tingkat putaran mesin tersebut tidak berpengaruh secara signifikan.

\section{KESIMPULAN}

Berdasarkan hasil pengujian konsumsi bahan bakar, trigger magnet mundur 90 menghasilkan data konsumsi bahan bakar yaitu $28 \mathrm{ml}$ pada rpm 6000, $32 \mathrm{ml}$ pada $\mathrm{rpm} 7000,28 \mathrm{ml}$ pada rpm 8000, trigger magnet 9,50 menghasilkan data konsumsi bahan bakar yaitu $24 \mathrm{ml}$ pada rpm 6000, $28 \mathrm{ml}$ pada rpm 7000, $24 \mathrm{ml}$ pada rpm 8000 dan trigger magnet standar 100 menghasilkan data konsumsi bahan bakar yaitu $16 \mathrm{ml}$ pada rpm 6000, $20 \mathrm{ml}$ pada rpm 7000, $28 \mathrm{ml}$ pada rpm 8000. Namun dari perbedaan hasil tersebut, secara umum tidak terdapat perbedaan signifikan. nilai $F_{\text {hitung }}$ untuk hasil pada jenis trigger magnet $=3.00<\mathrm{F}(0.05 ; 2,24)=3,40$ (ditolak $\mathrm{H}_{0}$ ) artinya memundurkan tonjolan magnet (trigger magnet) 90 dan 9,50 tidak berpengaruh secara signifikan. Selain itu, Fhitung untuk hasil putaran mesin rpm 6000, 7000, 8000 menghasilkan $=1.00<\mathrm{F}(0.05 ; 2,24)=3,40($ ditolak H0) artinya tingkat putaran mesin tersebut tidak berpengaruh secara signifikan. Jadi tidak ada pengaruh konsumsi bahan bakar pada trigger magnet yang dimodifikasi, maupun pada rpm 6000, rpm 7000 dan rpm 8000.

\section{DAFTAR PUSTAKA}

[1] Young, G.O. 1964. Synthetic structure of industrial plastics (Book style with paper title and editor) in Plastics, 2nd ed. vol. 3, J. Peters, Ed. pp. 15-64. New York: McGraw-Hill.

[2] Chen, W.K. 1993. Linear Networks and Systems (Book style) pp. 123-135. Belmont, CA: Wadsworth.

[3] Poor, H. 1985. An Introduction to Signal Detection and Estimation. ch. 4. New York: Springer-Verlag. 
[4] Krisbiantoro, D., 2009, Pengaruh Pengunaan CDI Variabel dan Variasi Derajat Pengapian Terhadap Unjuk Kerja Mesin Honda Kharisma Dengan 2 Busi., Jurnal Institut Teknologi Sepuluh Nopember., Surabaya, Universitas Teknologi Sepuluh Nopember

[5] Nanlohy, H.Y., 2012, Perbandingan Variasi Derajat Pengapian Terhadap Efisiensi Termal dan Konsumsi Bahan Bakar Otto Engine Be50, Jurnal Dinamika Vol. 3 No.2 Mei 2012, Kendari, Fakultas Teknik Universitas Haluoleo

[6] Machmud, S., Untoro, B, S., Leydon, S. 2013. Pengaruh Variasi Unjuk Derajat Pengapian Terhadap Kerja Mesin. Jurnal Teknik. 3 (1):58-60., Yogyakarta, Fakultas Teknik Universitas Janabadra. 